which enjoys facilities for large-scale experimentation through its member firms such as can only be available to industrial bodies of this kind. The research committee of the body organizing this work visited the Kingston and Fulham Laboratories of the British Coal Utilisation Research Association on September 9. Mr. J. G. Bennett, director of B.C.U.R.A., gave a short address, outlining the organization of his Association and the scope of the work it has in hand. Three main divisions can be distinguished, namely, the administrative, the general research division, and the specialized research departments, the latter subdivided into four or five sections. Within several of the specialized sections there are investigations in progress which will undoubtedly affect coke-oven practice and the quality of the coke that can be produced from a given coal or blend. In particular may be mentioned the 'heat-of-wetting' test developed in the Association's physico-chemical laboratory under Dr. D. H. Bangham. This, and other fundamental work on the structure of coal and coke, was discussed at the recent Conference on the UltraFine Structure of Coals and Cokes held at the Royal Institution. The visitors spent most of their time at Kingston, where they inspected work on the production of high temperatures from solid fuel and other interesting aspects before proceeding to the main building recently opened by Sir Edward Appleton.

\section{Otto Jespersen and an International Auxiliary Language}

EARLy this year Prof. O. Jespersen died in Copenhagen. He was a philologist of world-wide reputation who specialized in the English language, was the author of various standard works, and a firm believer in the practicability of an international auxiliary language. His work in this connexion has been ably summarized by $\mathrm{H}$. Jacob in a brochure published by the International Language (Ido) Society of Great Britain, in which we read of Jespersen's active part in elaborating Ido as a revised version of Esperanto; and of his subsequent invention, in 1928, of a new constructed language, called Novial. He was convinced that an international auxiliary language should be based on the material of European languages, should be regularly constructed, have a complete grammar of its own, be flexible and independent of national usages. He emphasized how incomparably easier it is to learn and use such a constructed language than any ethnic language, a view that has been confirmed as the result of a sixyears' test by Prof. Thorndike in the United States. English he regarded as easier than other languages, but it would have to be drastically altered, in regard to spelling, grammar, etc., to make it suffieiently simple for international use. Nor has Jespersen any use for Pidgin English: "it would be laughed at and mocked at, and all those millions who know and love the old English language would not consider it a serious attempt to solve an important problem, but would turn away with horror". The attempt to make English an international auxiliary language by reducing the vocabulary is held by many to be invalidated by the many different meanings which some words possess; thus the "New English Dictionary" ascribes sixty-four distinct senses to 'give', sixty-three to 'take', and twenty-five adjectival senses to 'clear'. As the outcome of a life-long study of linguistics, Jespersen believed that language is moving towards ever greater simplicity and perfection; and he quoted Turgot's saying: "Des hommes grossiers ne font rien de simple. Il faut des hommes perfectionnés pour y arriver". This Ido publication can be recommended to all interested in the subject, and especially as it shows no unreasonable bias in favour of its own language.

\section{Centenary of the Economist}

THE centenary number of the Economist worthily maintains the tradition of impartial examination of public affairs which it has established from the days of James Wilson and Walter Bagehot. The factual approach, acute analysis, constructive criticism and the flair for asking the right questions which have characterized it from the start are faithfully reflected in the pages of the centenary issue. Few periodicals can have done more to stimulate the consideration of social and economic questions in the cool serious spirit of science, and it is fitting that in congratulating the Economist on the attainment of its centenary; men of science should put on record their appreciation of the contribution which that journal has rendered to the advance of science. In the centenary issue scientific workers will find the articles on "Enterprise and Efficiency", on the Middle East Supply Centre, entitled "An International Example", on nationalization and on "Active Citizenship" of particular interest, but scarcely less stimulating and suggestive is that on "Britain in the World" and the review of the first hundred years and of the policy of the Economist which open the issue.

\section{Academy of Sciences of the U.S.S.R.}

THE continuing activity of the Academy of Sciences of the U.S.S.R. is indicated in information recently received from Moscow. Two sessions of the Academy were held in Sverdlovsk last year, and another is being held in Moseow this month. All kinds of fundamental research are being maintained despite the urgent claims of war work. Although in the U.S.S.R. scientific workers are exempt from conscription, many volunteered for military service when war with Germany broke out. It is vigorously maintained that this is a "scientists' war", demanding the continuation of scientific research, and in the list of essentials for victory achievements in mathematics, physics and agriculture are given equally high priority with achievements in fields more immediately associated with war. At the forthcoming session, thirty-six new full members of the Academy and forty-two corresponding members will be elected. Among the candidates for election are Drs. Kharkov, Kirill, Sinelnikov and Leipunsky, who are known in Great Britain for their work at the Cavendish Laboratory, Cambridge, and also the polar explorers Vladimir Bize and Nikolai Yukov.

\section{Earthquake in Japan}

According to radio reports from Tokyo, a serious earthquake took place in southern Japan during the afternoon of September 10. The area most affected appears to have been near Tottori, in which town half the buildings collapsed and more than 1,400 people may have been killed or injured. Tottori is some 100 miles north of Kobe where the earthquake was felt. The shock was also strong at Osaka. Around Tottori railway lines were blocked and telegraph communications were interrupted for a distance of 60 miles to the west. So far no news has been given concerning the area east of the town. Further news 